\title{
INTERVIEW WITH MILAN HERAK "GRADUAL COGNITION OF KARST PHENOMENA"
}

\author{
conducted by IVO LUČIĆ
}

We are continuing our series of interviews with key players in karst studies of the last century. In this issue, the interviewee is Milan Herak, professor emeritus of Zagreb University and a long-time full member of the Croatian and corresponding member of the Slovenian and Austrian Academies of Sciences and Arts. Professor Herak has an impressive, 70-year long research and teaching record in various fields of geology. He was among the first stressing the relation between geologic structure and karst features. He published more than 200 works, including several fundamental textbooks on geology, and served as an editor of several journals and books. He co-edited the book Karst: Important Karst Regions of the Northern Hemisphere, which has become one of the classic and world-wide recognised references on the regional karst distribution. The CV of prof. Herak is online at http://www.sazu.si/osazu/clani/milan-herak.html.

Franci Gabrovšek Co-Editor

\section{MILAN HERAK \\ Professor Emeritus, Zagreb University, Croatia}

Dear professor Herak, I thank you for your goodwill to take part in this interview. Allow me, first, a personal question. I know that you have already passed 92 years, and therefore, I would like to hear how you feel, and what are your next plans?

As my feeling is concerned, the sincere answer may be that I feel as a person who is physically declining but intellectually, more or less, constantly active in different ways, from research and discussions to everyday dealings (some home activities, reading, short walks, radio, television, etc.). Now, I am preparing, in cooperation with some younger researchers from the Faculty of natural sciences and mathematics and the Croatian geological institute, a study concerning the mutual relations of the Alpides and the Dinarides. The published documents available, due mostly to specific orientations of the researchers, are very disparate and require additional correlation and, even, emendation in order to gain reliable mutual characteristics. For this purpose, also the karst areas are better known, because their tectonic phenomena have been additionally confirmed by dye tests in swallow holes and in boring holes and by geophysical measurements which have been accomplished, mostly, for practical purposes. Concerning the karst, I think about it, very often, even when it is not in my first plan.

It may be of interest to know when was your first contact with karst features; was it in your childhood, or afterwards during your school years?

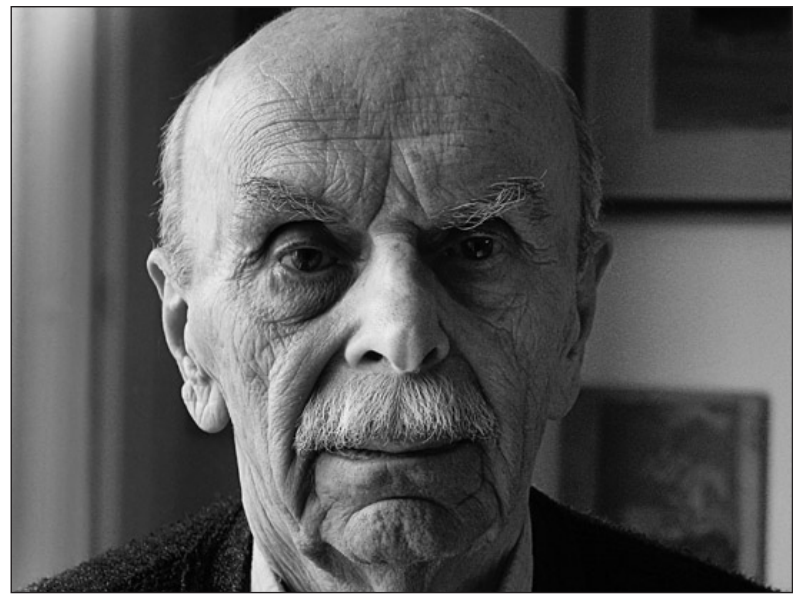

Milan Herak, recent photo by Ivo Lučić.

My cognition of some karst features was gradual, starting with my childhood and lasting till now. My first encounter with them started with my first consciousness of my natural environment. I was in a small village, Brašljevica, in Žumberak (western Croatia) on the very entangled boundary with Slovenian Bela Krajina. A small and narrow Croatian part penetrates into the Slovenian territory. It is interesting that the geological relations are, also, intricate and poor in surface waters. As a matter of fact, there is only one brook, called Babinac, approximately one kilometre distant from the village. The potable water percolates from the Slovenian side. It was very important for my village, because, for centuries, this was the only natural source of drinking water. The first improvements in furnishing water were cisterns, 
and after some decades, finally, an aqueduct crossing the Slovenian territory. In the before-mentioned joint Croatian and Slovenian domain are to be found two types of land surfaces. The greater one is almost lacking in surface water streams. However, it is obvious that there exist relatively shallow karst streams, even under the Cretaceous marl deposits, which overlie fractured and therefore permeable Jurassic limestones. In one of the dolines within the village, a ponor (swallow hole) is present. In the slowly lowering Slovenian terrain the Jurassic limestones are sporadically outcropping, mostly through the cultivable land. In the covered land masses the subsurface water is percolating, making a shallow karst water net which is, also, furnished the Croatian covered karst.

You mentioned buried dolines. Are there any other obvious superficial karst forms?

Not numerous, but two uvalas and a periodic brook, in a relatively deep stony bed, may be mentioned. One of the uvalas, called "Luka", is located in front of Brašljevica. I retain it in my mind as an elongated and lowered meadow, which periodically was flooded by intermittent outlets and disappears in the ponors at the other side of the uvala. The lake conditions are, mostly, of short duration.

The second uvala, named "Polje", is situated something less than two kilometres southeast of the village. It was our best pasture-ground because there is a permanent spring that flows along the "polje" and at its lower end disappears into the ponor, where it is joined with the shallow subsurface water net which is flowing in the direction of the Kupa river. This ponor is named "Peretina bezdan" (= Peter abyss), which recalls the possibility of incautious or voluntary fall in without escape. I still remember quarrels with such threats, especially between some spouses. Fortunately, I do not remember any such end. Instead, usually reconciliation followed.

The third essentially different karst phenomenon I noticed in the western part of Žumberak. It is a question of a torrent which varies from water-rich to completely dry brook bed. For the natives, this is a quite ordinary phenomenon. I never heard anybody connect that periodically dry bed during drought with the possibility that the water stream exists under the surface in the direction from Metlika. I became conscious of such a possibility later on, when I had more experience with karst relations.

\section{later on? \\ Did this happen already in secondary school, or \\ When I left Brašljevica, I had too many new prob-} lems and only rarely recollected the happenings in Brašljevica. In my memory remained, mostly, my village, arable land, meadows, vineyards, orchards, and the view of the only mountain at the horizon, named Klek, where, after the common people's belief, the "witches" gather. On the other side, Zagreb, with its municipal lifestyle, was for me something completely strange. The new school with separate courses, many teachers and books required much more than I expected. However, very soon, I was accustomed to the variety of teaching courses and, at the first place, of the natural sciences which were most interesting for me, because they reminded me, at least partially, of my childhood in Brašljevica.

Despite the diversity of teaching subjects, my scarce karst impressions were not considerably increased. I learned that the Croatian term for "karst features" is "krš", Slovenian "kras". I connected this with the verb "kršiti" (crash, destroy). Besides, I learned that "krš" in Croatia is very extensive. Also excavation in Krapina was mentioned, where Dragutin Gorjanović Kramberger discovered the fossil bones of "Diluvial Krapina man" together with the fossil rests of the cave-bears and other animals that were looking for shelters in caves during Pleistocene glacial periods. However, though my notions on some karst features of that time were only fragmental, some of them have been included in my later karst research.

\section{Study of natural sciences was your next option.}

It was a normal way. In the year 1937 I chose the Faculty of philosophy at Zagreb University and decided to study natural sciences, including geology. My favourite was botany. However, professor of geology Marijan Salopek invited me to summer field exercises in geological mapping in Lika, especially in the area between Sv. Rok and Gračac. There I noticed some phenomena which were for me very interesting, but strange, not only to me but also to the advanced students and even to the professor. It is a question of lost rivers and brooks that flow towards Velebit Mountain, abruptly sink on its northern foot and flow below the surface in the direction of the sea. Velebit was considered to be a consolidated antiform. In that case, the subsurface water courses may be possible only along distinct cross faults, which had not been noticed. Later on, my applied hydrogeological investigations suggested that this phenomenon may be explained with the help of tangentially disturbed structures, in which karstified limestones may be buried under older, especially Paleozoic, impervious deposits. Similar assumptions have already existed, but more on geotectonic than hydrogeologic bases. The possible solution had to await new tectogenetic considerations.

Would you comment on your post-graduate scientific study?

The answer requires remembering the Second World War. When I finished the study of natural sciences, I had to await the invitation to military service and probable inclusion into the war, which I tried to escape. And I succeeded in it, by getting permission to continue 
"informal" postgraduate study in Vienna. My first scientific activity occurred in the museum of natural sciences. At the same time I was the "guest-student" at the Geologic department of the University in Vienna. There, I had occasion to know two very experienced researchers, and learned from them insights which, later on, were important for my scientific activity. The first was Julius Pia, the head of the Geologic department of the Museum. He was a famous paleoalgologist, who stimulated me not to forget to start, later on, with the investigations of fossil algae from the Dinaric karst, which is rich with their fossil remains. The second scientist was Kurt Ehrenberg, professor of palaeontology and a specialist for cave-bear investigations, which was obvious in contacts with him.

\section{What was your initial scientific interest?}

At first I got the opportunity to realize some ideas, gained from my teachers in Vienna. By chance, in the Geologic-palaeontological Museum in Zagreb I noticed the collection of cave-bears, and also of rock samples rich in remains of fossil algae, for which, till then, nobody was interested. I tried to give attention to both of them. I published only one paper on the cave-bear, while the fossil algae have been my research objects for decades. During my examinations in karst areas, I collected new samples of algae. Moreover, I got new samples as well from our geologists, as from Austria, Germany, Slovenia, Monte Negro, Herzegovina, etc.

Probably you soon returned to field investigations.

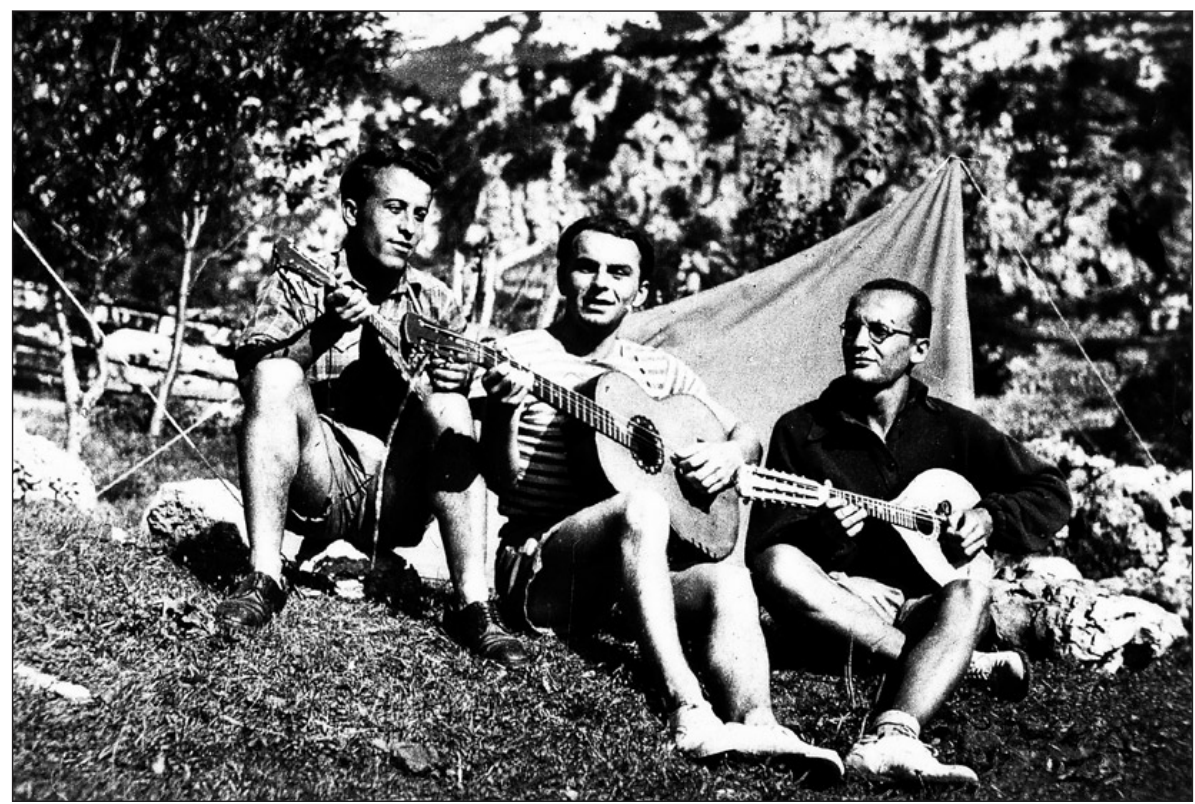

1930 in Paklenica (Adriatic slope of Mt. Velebit) amateur music supplement to "weekend" evening entertainment, after six days of field exercises with colleagues Ivan Crnolatac and Radovan Domac

In Vienna I prepared a palaeontological manuscript on calcareous sponges. It was, later on, published as scientific paper, in Stuttgart 1943.

How long lasted your study in Vienna?

Not very long, only 6 months. Then, due to my disease, I had to return home and was made free from military service. However, I did not lose my scientific interest, and I came to the idea to apply my already printed paper that was finished in Vienna as a doctoral thesis. It was accepted, and in 1943 I achieved the grade (now we would say) of doctor of sciences. Soon after that, I was employed in the Croatian geologic-palaeontological museum. With this, my formal education finished and my further progress in research was very manifold.
For some time, the post-war conditions were not suitable for intensive field work. Therefore in 1946 I organized our first field trip to Žumberak. My oldest brother, who remained to live in Brašljevica, provided our sojourn in my native home. In the group were Josip Poljak, Ivan Crnolatac and Donata Neděla Devidé. I was very curious how the known karstologist Poljak would comment on the small karst phenomena in the surroundings of Brašljevica, especially those ones which belonged to the areas of veiled tectonic relations. Donata was especially interested in visiting the finding place of fossil remains belonging to the "cornlike" pelecypods (rudisteds), where my brother, stimulated by our former conversations on fossils, had gathered a worthy small collection of well-preserved exemplars. We visited the locality and supplemented the collection, which is still guarded in the Geologic-palaeontological institute of the Faculty of natural sciences and mathematics of the University of Zagreb. The small karst phenomena have not been especially commented upon, with the exception of a small cave in the upper area of Babinac brook.

Soon after Brašljevica, we visited the surroundings of Knin in Dalmatia, where I collected some interesting samples of calcareous algae. One among them deserved special attention because it was obviously different from the others. I described it as a new species under the 
name Physoporella croatica. The paper was published, on request, in the journal of the Palaeontological Society of India, 1958.

This all is interesting. As I know, the scientific term "hydrogeology" was first used by British geologist Joseph Lucas in 1888 (Mather 2001). However, I would like to know when and how you came to the term "karst hydrogeology"?

For a long time, karst waters have been treated only in the frame of karst "hydrology". However, for explanation of some data, it was required, also, to know their geological basis. Without it, it was impossible to establish the distribution and the flow directions of subsurface karst water systems. In our practice, it was confirmed very soon, 1946, when Josip Poljak was invited to evaluate the geological part of the project of dams for establishing artificial lakes in the valleys of sinking rivers at Lokve (Lokvarka) and at Fužine (Ličanka), in Gorski Kotar. The accumulated water had to be, and is, the propelling factor for the power plant in the Vinodol depression near the Adriatic coast. Poljak accepted the invitation, and gave the opportunity to me, Neděla and Crnolatac to accompany him in order to see how general geological knowledge could be applied in practice. To designers, the proposal to inundate by stored water the karst spring of Ličanka, was very suspicious, and the place for the dam too wide. Moreover, the available documentation was not suitable enough for definite conclusions. However, soon after our arrival, we noticed some tectonic elements which had not yet been taken into account. Therefore, it was proposed to reinterpret and supplement the corresponding geological map. We did it, and it became clear that the inundation of the karst spring would, really, mean a great risk. Instead, we were of the opinion that the location of the dam could be displaced close to Fužine, where the dam would be much shorter, and storage capacity greater. Despite some suspicions, the so-designed project was performed without any difficulties. rest?

Did this experience widen your scientific inte-

Naturally. Though our investigation finished positively, some scientific questions remained unsolved and intrigued me for the next decades. The greatest enigma concerned the results of dye tests of a sinking brook at the village Vrata, outside of the planned storage basin. The achieved results showed that there exists an unexpected subsurface connection between the ponor and a copious karst well in the adjoining Lič polje, on the other side of the impervious belt consisting of Triassic dolomites. This was the reason for my frequent visits to complete my field data. However, I waited long for the probable answer, which was conditioned by the change in the basic tectonic pattern by introduction of mobilistic, underthrust and overthrust approaches into considerations.

Your second research field was in Lika, in the area of the sinking river Zagorska Mrežnica?

This was not planned. It happened while Poljak was busy with other important engagements. Therefore, unexpectedly, he sent me to start independently with preliminary investigations. It was a question of a planned storage basin in the valley of the sinking river of $\mathrm{Za}$ gorska Mrežnica, near Ogulin, at the foot of Mala Kapela Mountain, between Gorski Kotar and Lika. The reason was the verification of disparate conclusions from geophysical measurements on the one side, and deep boring data on the other. The problem was the geophysical supposition of the existence of subsurface hollows under the chosen location of the future dam, which had not been confirmed by drilling. When revising the geological documentation, I found in the Triassic dolomites calcareous algae. As they have been very reliable index fossils, they confirmed that the dolomites cross the river bed and suggested that the waterless hollows were not probable. The very shallow bore holes have proven that, instead of hollows, impervious clayey beds are present. This meant that the location of the dam was safe and that the deep borings could be stopped. So the project was saved and carried out. As the new geological interpretation, it was formulated as a scientific manuscript, which was accepted and published in 1952 in the Croatian (ex-Yugoslavian) academy of sciences and arts. This was a definite affirmation of the similar procedure applied in Fužine and Lokve and an additional indication that the cooperation of "poor" geology and "poor" hydrology make a complex investigation branch ("hydrogeology") with benefits for both constituents. This means that for karst evaluation it is necessary to approach it as a tectogenetic problem. This was the basis for the conclusion that an abundant karst well, within the planned storage basin, can be inundated without danger of additional water loss. This was well accepted by designers. But, it remained to convince Poljak; then he almost dogmatically was of the opinion that karst wells are not at all suitable to be flooded. Therefore, I applied the tactic that several times was successful. I did not force my opinion, but I asked him does he not think that, in the given conditions, the flooding may be permitted. In such a case he thought it over, and the answer was in most cases positive. This happened even concerning this storage basin. The rightness has been confirmed by the dam and storage basin without subsurface water losses. This combined practice was applied in all the following "hydrogeologic" examples.

You evidently included your results in your teaching courses at the University? 
Naturally, I did it without any delay, firstly at the Technical Faculty of the University of Zagreb. This happened at just an appropriate time, 1952. At that time, a group of mining engineering students were selected to study new combined courses to achieve the grade of engineer-geologist. It was especially important, not only to widen the courses of fundamental geology, but also the new course was formulated under the name engineer geology and hydrogeology. Thus, hydrogeology found its first official usage in our teaching program. As petrogra-

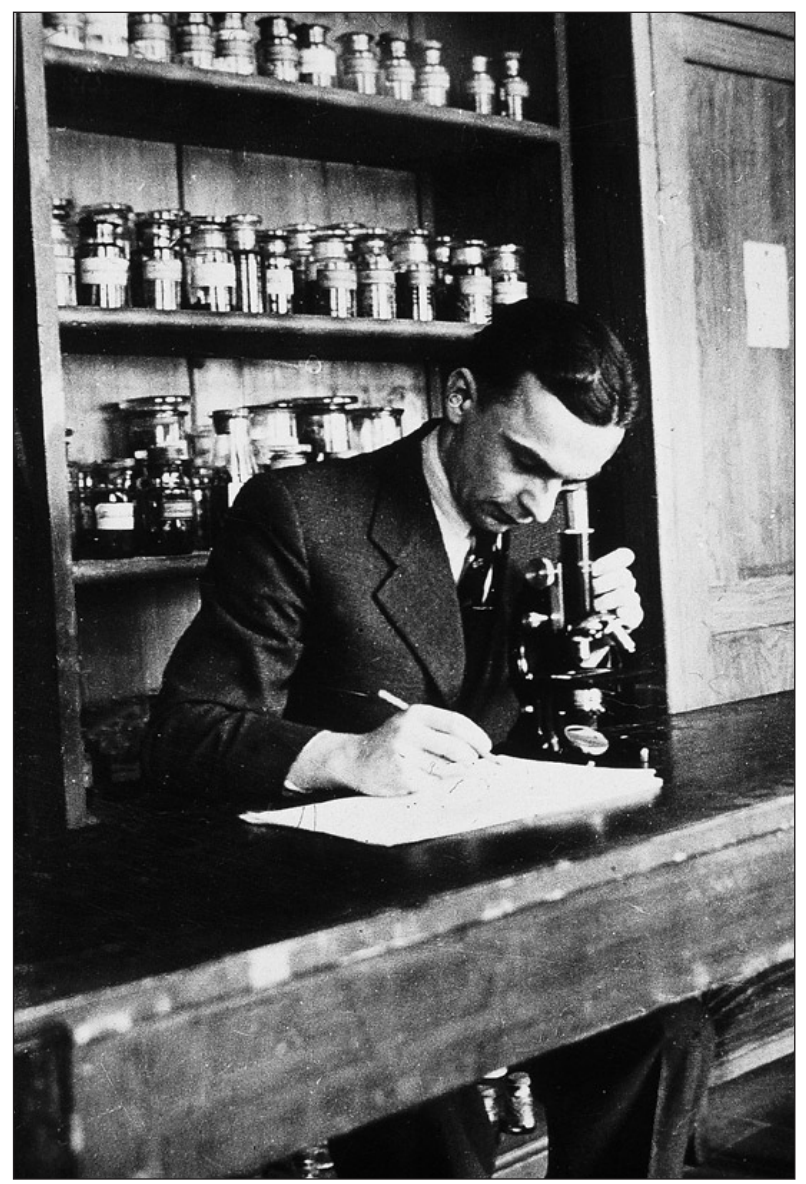

Final preparation for graduation examination 1941 in the Botanical institute.

phy was a separate subject of teaching, it was necessary to select the applicable subjects from fundamental geology, and instead of the term "applying geology" I introduced the term "applied geology". The quantitative material I added from then-existing textbooks, which were not integrally applicable.

The results of the mentioned new branch of studies were successful, because many of the candidates graduated as engineer-geologists, and some of them acquired doctoral degrees and so, even formally, were qualified to accept very responsible professional obligations (professors, chairmen of institutions, including the Croatian geological institute, which, informally, have performed the function of the Geological Survey).

As I am informed, you retained your double (fundamental and practical) activities even when you removed to the Faculty of Natural Sciences and Mathematics. However, you continued with investigations for practical purposes, and with teaching on both faculties. Why did you change faculties?

The main reason was the retirement of professor Salopek, my first teacher in fundamental geology. As a naturalist, who had some experience in the application of geological notions in practice, I accepted in 1958 the opportunity to return to the Faculty, where I had started with geological research activities. However, I did not stop teaching fundamental geology at the Technical faculty.

My return to my primary Faculty offered me the opportunity to formulate my scientific karst experiences in different karst domains as a new teaching subject under the name "Geology of karst" that was constantly enriched by new achievements of results, including the data acquired by my students of fundamental geology. At the same time, I was obliged to teach regional and geotectonic problems. And, just my knowledge concerning these subjects was the reason for my obligations abroad, when I was invited to help in explanation of fundamental geological problems, as a basis for the treatment of practical geological problems.

At home, I had the great support of my students who already were engineers and doctors of natural or technical sciences. In these collaborations, I gained copious samples of fossil calcareous algae, which have been applicable in explaining not only stratigraphic problems, but also some tectonic ones. Therefore, I got the opportunity to present the gained results as well at home as in foreign publications. Moreover, I presented them at the International geological congress in Copenhagen, 1960. In parallel, I remained interested in investigation of geological bases for explanation of some karst hydrogeological problems.

Will you illustrate this by some examples?

The first one is connected with the area between Gračac and Sv. Rok in Lika. There, as told above, I had already in the study observed loss of surface water under Mt. Velebit, in the direction of the Adriatic Sea. Then, I had not conceived why the water flows under Velebit. But, not earlier than when I accomplished additional research based on calcareous algae, I established that a structural barrier consisting of Triassic beds urges the climbing of waters in the spring area on one side and allows disappearing of water streams on the other side of the structure. On this basis was designed the construc- 
tion of the storage basin, which, through a tunnel, supplies the working water for the power plant located some distance above sea level near Obrovac. Even more, as in the case of Zagorska Mrežnica, the acquired data have been used for publishing a scientific paper, in 1960.

An important methodological enrichment occurred during investigations in the upper area of the river Kupa, in Gorski Kotar, especially around its karst well, for purposes of preparing the geological conditions for designing storage basins. The standard impression was that it is a question of a compressed autochthonous tectonic complex. My collaborators were Luka Bojanić, Dragutin Šikić, Antun Magdalenić and Vladimir Cukor. The results astonished, not only us, but also other experienced geologists. Namely, instead of their assumed compressed structures, in which the cores should make impervious Paleozoic beds, we established that this terrain is very disturbed due to allochthonous tectonics, and that not only Paleozoic but also Triassic deposits overlie the karstified Jurassic limestones. This was a very important factor which required a serious precaution in planning the location and height of the proposed dams. As well, it required carefulness in the case that the karst spring of Kupa might be flooded. Not only due to these warnings, the storage basins and dams are not yet designed.

Perhaps, the most intrinsic were the examinations of Plitvička jezera (Plitvice Lakes), divided from one another by magnificent waterfalls. Although they are surrounded by deep karst, there are no indications for loss of water in the underground. Long ago, we were looking for the reason for such a phenomenon (Vukotinović, Gavazzi, Koch, Pevalek, etc.). The most common answer was that it was connected with the folded dolomites and limestones, which in that time were attributed to the Cretaceous. In the area of the upper lakes, older impervious dolomites, as a barrier, underlie the younger permeable water-bearing limestones. Between the lakes the tufaceous deposits are originated, becoming the basement of very differentiated and beautiful waterfalls. The hydrogeologic relations became more simple when the dolomites were attributed to the Triassic. In that case, they should be underlain by impervious Paleozoic deposits, preventing loss of water from the upper lakes. However, the problem of the lower lakes, due to lack of the Triassic dolomites, remained more difficult to solve, as well as the presence of small caves and caverns along both slopes along the lakes. Finally, the impervious structural element has been found in the form of Cretaceous watertight marl intercalation, which prevents the underflow of water to the north below the main fall. At the same time, this means that subsurface waters from the stony land on both sides of the lakes can be discharged towards the lakes. This explains the origin of the mentioned small speleological phenomena. Concerning these notions, I presented at the Geologic Congress in Beograd, 1962. However, the response has not been adequate to the new notions. The consequence, even up to now, is speaking of "uncommon" characteristics of these impressive lakes, without giving any scientific explanation of their origin and incomparable beauty.

\section{When did the experiences abroad follow?}

The beginning was entangled and very interesting. From the year 1964 I had more and more opportunities to check my treatment of the interconnections between tectonics and hydrogeology.

The international Food and Agriculture Organisation (FAO) was looking for an expert in karst hydrogeology who could help to determine the extent and scope of intake areas in Jamaica, especially of a well which has been most important for water supply. Evidently, they wanted one who is familiar with the Dinaric prototype of the deep karst. Ante Šarin, my ex-student, was asked to recommend somebody, and he recommended me.

With respect, I accepted the proposal and departed to Rome for instruction in FAO, and proceeded to Kingston, the capital of Jamaica, which was the seat of the project with Dawid Wozab as chairman. Within eight weeks I visited all interesting localities and studied the correspondent publications, and had discussions and prepared my expertise for FAO. The geological basement is more or less simple. However, there were acquired some new notions which it was necessary to discuss with Wozab. We had not been unanimous in every change of standard interpretation. Alteration for the better came when I concluded that the extent of an intake area should be approximately sixty square kilometres, instead of six as was, before, proposed by a group of foreign hydrologists upon the topography. Without knowledge of their report, I based my conclusion upon taking into account even poljes, intermittent springs and ponors. Later on, Wozab informed me that my evaluation was rather in accordance with the theoretical calculation of his group.

After returning to Rome, I was more than satisfied, while the authority of the FAO expressed great pleasure after being acquainted with my report. This was my first international obligation, but not the last one.

As I understand, the case of Jamaica was a starting point for your further karst activities abroad.

Partially, yes. Namely, I had two main kinds of collaboration partners for activity abroad, FAO and Unesco on one side, and hydrotechnical organisations.

Let us begin with FAO. In Dubrovnik, 1965, an international meeting on water problems in karst areas was organized. I was, also, there and presented a short review of achievements in Jamaica, prepared by Wozab, who could not arrive. I was a little astonished that there was 
no discussion. However, afterwards, I heard some commentaries that problems are very entangled. This meeting had an additional signification; at the end of it, an international group for investigation of waters in "fracture" (= karst) rocks in the Mediterranean domain was established. In addition to the countries around the Mediterranean Sea, also the USA, Soviet Union, Austria and Netherlands were included. The first chairman was our prominent hydrologist Milivoj Petrik. I was not invited, but relatively soon, without my knowledge, I was elected as successor of Petrik, but only as a delegate. The chairman had to be elected at the first session in Rome. To my surprise, the delegate of the Soviet Union proposed to elect me for this responsible obligation, probably due to my experience in the Dinaric karst. I was elected and, after three years, re-elected. We have had many meetings in different countries, with discussions on numerous different problems. When I was elected for the second time, the member of the FAO David Burdon proposed to the Group to oblige me to visit all the countries where the exploitations, including drillings, in order to exploit karst waters, were in course and were financed by UN. I had to verify the results, visit some of characteristic localities, collect the karst terms and, in every country, at the end of the visit, I had to inform somebody from the government of my impressions.

How much time did you spend to accomplish this obligation?

Approximately two months, in every country 9 days, and the rest in Rome (FAO). After my return to Rome the group at its next session accepted, without any special comment. At this opportunity, I enriched my knowledge not only on karst domains in the whole Mediterranean domain, but also on the regional geology and my teaching programs at the universities in Zagreb, Sarajevo and Beograd, as well as in the different associations in Split, Sarajevo, Beograd, Vienna, Warsaw, Rome (FAO), Tunis (FAO), etc.

What other consequences of it can you mention?

Very soon, I was engaged by hydrotechnical enterprises from Zagreb, Beograd and Sarajevo as a consultant in evaluation of hydrotechnical projects abroad, especially in Lebanon, Turkey, Iran and (on request of Wozab) again in Greece (Peloponesus).

Especially interesting was my visit to Iran, where I was the consultant, not only of our designing enterprise, but also, of the Iranian government in order to visit and evaluate their exploitation activities at many localities in their karst areas. At the end, I referred my impressions to their prime minister. I dared to express my wonder why, for practical purposes, the Iranian karst was divided in several independent karst areas. Hence, over ten separate working groups were organized, in conviction that the quantity of available subsurface karst waters depends of the number and depth of new boring wells. Therefore, they were surprised when I warned them that it is quite possible that in several adjoining wells the same interconnected groundwater may be exploited. Therefore, the planning of new boring-wells should be very carefully carried out, which means that the hydrogeological parameters have to be much more taken into account.

\section{However you did not finish your obligations to} FAO?

Formally not, but in fact, there remained to publish my original report connected with my journey in the Mediterranean domain (1969), four lingual terminological dictionary (1972), and my enlarged text on hydrogeological and hydrotechnical problems in eight characteristic countries (1973), as a product of the group, which after six years ceased its activity.

What was the benefit of your such complex activity?

First of all, the before-mentioned happenings inspired me to enrich my scientific publications by proven data connected with practice, independently or in cooperation. At the first place I point out our well documented commentaries upon the meaning of geology for the origin of karst types and their domains, in Split (1969), then of its significance for hydro-technique in Zagreb (1969), Montreal (1970), Zlatibor in Serbia (1973), again in Dubrovnik (1975) when, at a Symposium, the investigation results were presented concerning the bilateral research program in U. S. - Yugoslavian cooperation in the field of hydrology and karst water resources, pollution and economic development. The contributions were prepared by hydrologists, hydrogeologists, hydraulic engineers and water resources specialists, not only in our countries but, in general, around the world. Ecological evaluation of karst was also included in considerations of karstologists. The publication in New York (1996), may be mentioned as an example.

Your interest in the hydrogeologic manifestations in karst areas is obvious. Have you any new comments concerning geomorphologic karst features?

Certainly. I have had some interest in karst geomorphologic phenomena, because they were and are very important due to practical reasons (storage basins, tunnels, etc.) of the surficial and subsurface water bodies. Superficial units like poljes, uvalas and valleys have been of interest, mostly, in the cases of possible construction of artificial water storages for power plants or irrigation of arable lands, orchards, etc.

The fractured areas, dolines, pits and ponors have been interesting as places where superficial water streams are sinking into the karst underground or are subsurface reserves for artificial potable and thermal water supply. 
They are so differentiated in form and origin that their distribution can hardly be uniform in greater extensions. Therefore, they require more individual treatment, which may be interesting, also, for general scientific studies. For example, the dolines may be originated either by the activity of sinking waters in the fractures of carbonate soluble rocks or due to erosive and corrosive factors of subsurface waters that causing the thinning and collapse of roofs over shallow subsurface cavities and, thus, stipulate the origin of collapse dolines, pits and other subsided superficial karst forms.

On the contrary, the plains and karst poljes were and are much more intricate surficial megaunits, which display more tectonic than corrosional consequences and, therefore, still require a better knowledge of general geological notions that may be important for reconstruction of their origin and extensions. The tectogenetic approach suggested interconnection between the underthrust tectonics of the units and their current structure and configuration. According to this, the general structural pattern of plains and poljes may be assumed as parts of the far extended allochthonous megaunits. This means that their final pattern is a consequence of several interconnected events, as are lithogenesis in primary environments, horizontal, tangential and vertical disturbances, rock alterations, their horizontal and vertical disordering and removal due to abrasion and erosion processes. In this way only a disordered heterogeneous basement has remained, being exposed to surface and subsurface corrosion and solution carbonate rocks, disordering already present structural elements and creating new forms. For example, erosional remnants, small cavities and karren are products of localized tectonics, selective erosion and corrosion, while waterfalls, smaller cascades and different other speleothems are solution and precipitation products. Only smaller constitutional units may have been modelled due to additional localized tectonics and entangled surface water activities, as are erosion, solution, etc.

Some of the mentioned factors have acted, also, in the underground. Probably, these activities have been interconnected.

They were and are. However, the subsurface cavities have never attracted me to an active cooperation in their explorations in situ. However, I had interest for the discoveries of other researchers, especially if they are located in areas that are interesting in the geotectonic sense. Two of them I especially esteemed. The first was the very experienced speleologist Josip Poljak, who made a doctoral thesis on speleology. The other who impressed me is my ex-student Srećko Božičević, who enthusiastically tried to overcome plenty of obstacles in caves and channels, regardless of whether they were cataracts, nar- row and steep paths, siphons, etc. Although many of his explorations have been done to acquire reliable data for hydrotechnical projects, his respectable final results were inspiration for his doctoral thesis in speleology.

The previously stated does not mean that I do not admire speleothems, cascades, rich water flows, traces of life, and even the purification processes of polluted waters flowing over the cascades, disappearing in siphons, etc. Despite all of this, I preferred to observe the happenings on the earth surface.

Due to my specific interest in hydrogeology, I have been especially curious about the geological role in the origin of underground single phenomena, like caves, caverns, pits, cascades, which may be very diversified due to variation of cracks, joints, fissures, fractures, faults and folds and the grade of solution of carbonate rocks, from which process the origin of different speleothems depends. Their distribution is a consequence of direction and amount of flowing subsurface waters. Such specific data may be used for anticipation of needed exploration works, mostly for scientific and practical purposes.

Your engagements have been very different and responsible. Nevertheless, you accepted the proposal of Elsevier in Amsterdam, to organize, as chief editor and author of some chapters, preparation of a book that would correlate the karst phenomena in several important regions of the northern hemisphere. You have done it with co-editor V. T. Stringfield. Would you tell me how this project was going on?

This was a very complicated engagement. At first, I had to contact the possible authors of general and regional chapters, skilled not only in karst problems, but also in its geologic basement. Many accepted the proposal. My intention was that karst areas of all selected countries may be treated at the same level, which means that even the specific manifestations may be correlatable. My proposed subjects required a treatment in which all important interrelations between the morphology, hydrology and geological dynamic and structural pattern of different karst domains may be comprised. This, probably, was too entangled for some of the foreseen authors. Therefore, the planned countries have been reduced. The procedure to prepare manuscripts for print lasted several years. This is an obvious testimony that the requirements for some of them were too difficult. Every manuscript had to be sent to me for correlation of geologic factography and its evaluation. Then, the manuscripts were transferred to Stringfield who, with help of his daughter, made the linguistic control. Although the manuscripts were not mutually adapted, they were transmitted to Elsevier and published in 1972. One of the important requirements was the differentiation of karst domains in "geosynclinal" and "epi-continental" karst types. By the 
way, later on, these terms have been renamed as "orogenic" and "epi-orogenic" (or maybe epi-platform) karst types. Both of them are characterized by specific generic environments, adequate dynamics and consequences which make possible some hypotheses, important for further explorations.

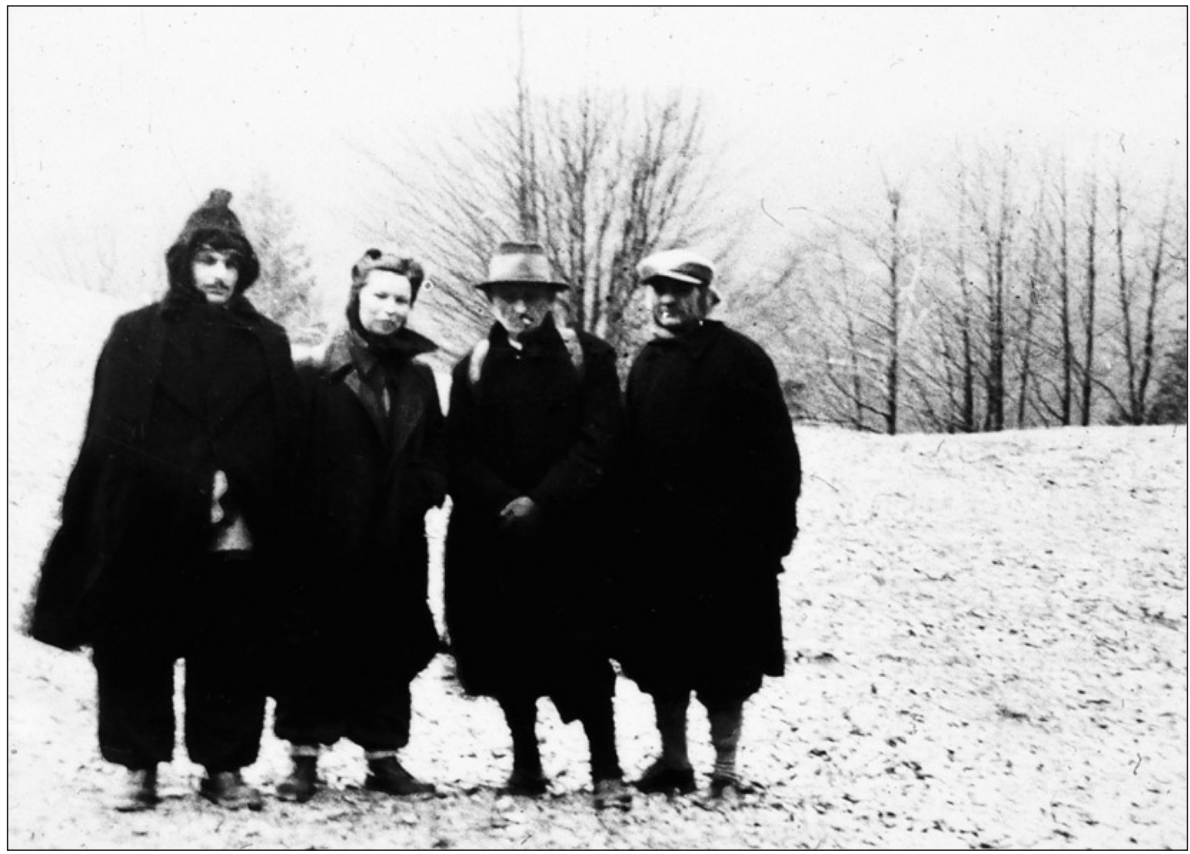

Fužine in Gorski Kotar, March 1946: Unusual start of hydrogeologic investigation in the by snow covered terrain: Milan Herak (with hood), Donada Devide, Josip Poljak and Ivan Crnolatac

thrust (or underthrust) complexes of mountain belts, as well as in the less uplifted and relatively rifted surfaces like plains, uvalas and poljes. The last mentioned karst complexes have been additionally sculpted by freshwater activities, especially by destruction due to corrosion and erosion, and creation by precipitation of tufa, modelling new cascades, which are interesting in the hydrodynamic sense, and different speleothems as "decoration" elements. Up till now, they are present even in allochthonous structural units, not only in the Dinarides and Alpides, but also in other, especially Mediterranean, mountain belts. The final modelling occurred by help of rifting and (possibly) gravitational displacements of single rock megaunits, giving the possibility of erosion and denudation on the surface, and retaining interconnections between their surface and interior water net systems. Due to the mentioned factors, entangled specific features originated on and within the very neotectonically more-

You applied those notions in the interpretation of the Dinaric karst areas. Are they all belonging to the orogenic karst?

In general, they do. However, the later-established oceanic and continental north or northeast directed mobilism has initiated an assumption of more diversified geotectonic occurrences, which did not change the already known hydrotectonic diversification in the Adriatic, High karst and Inner domains. However, the up-to-date explanation of their geotectonic setting requires greater diversification of the whole megadomain, and suggests taking into account more differentiated causes and, consequently, their more intricate allochthonous south or southwest verging common boundaries. Nevertheless, their orogenetic characteristics have remained, suggesting that these karst areas preserved even primary karst phenomena, formed in carbonate rock complexes, generated in labile megatroughs, earlier called "geosynclines", embracing sea or ocean waters. Therefore, the first karst conditions existed already in the process of orogeny, and hence their main distribution is in the very disturbed, folded, faulted, and over- or-less disintegrated continental blocks, especially in their marginal parts that are close to the remnant sea or ocean salt water megastores. In all these cases, it is a question of very disturbed deep karst domains, characterized by irregularities in their surface and subsurface water nets. Therefore, any explanation of them as common types is very difficult, especially in marginal zones where mixing of fresh and salt waters occurs at overflowing springs conditioned by impervious flysch zones, or where water underflows the "hanging" flysch belts in submarine contacts with the underlain karstified carbonate rocks. The patterns of such relations may be very different in single megabelts. The most complicated seems to be in the Adriatic and peri-Adriatic parts of the Dinarides, where the only main water contacts between their central body (omitting the general slope surfaces) and the Adriatic Sea are conditioned by perpendicular faults or due to the allochthonous pattern systems. Between them, larger stores of stagnant or dynamic fresh water bodies can, much easily, be formed. On the contrary, some other belt systems, like the Hellenic one, are drained mainly along their structural 
drainage systems and, therefore, are less convenient for subsurface water accumulations.

However, even the Dinaric karst has been often subdivided. Why?

The reasons for its subdivision are great regional differences, with very entangled structural variations and interconnections, which for practical reasons require individual treatment. In general, it is most often divided into three sub-domains with obvious specific characteristics, like the Adriatic karst area, High karst area and Inner isolated karst units. In our publication on Karst (1972) they are treated in their characteristic details, which may be shortly paraphrased.

The Adriatic karst region comprises the islands as isolated karst bodies, their common sea bottom and its transition to the coast line belonging to the deep karst domain. The islands are single small karst bodies. Their structures have been, for a long time, ascribed to folding and faulting, only. However, at the surface of some of them have been established also tangential ("overthrust") tectonic units. Deep bore holes executed for oil and gas exploration, as well as geophysical measurements, have confirmed the "imbricated" structures in the depths of the islands and under the sea bottom. Besides, the morphologic diversification of sea bottom and open land continues below the main coastal belt. Therefore, the subsurface fresh water circulation is much more complicated than it was believed before. Due to tangential south or southwest vergent structures, the impermeable Paleogene flysch zones assumed the function of relative barriers, influencing not only the subsurface water streams from the mainland into the sea at the marginal springs along the coast margin, but also the sea bottom springs (vruljas), which, during the low ground water level in the hinterland, may become "intermittent" sea estavelas or periodical sea ponors, through which the encroaching of sea water into the land hydrologic system of islands or of the coast line, occur. The consequence is the presence of brackish water even within coastal structures. The hydrodynamics at such localities depends on atmospheric influences on sea water tides, fresh water exploitation, etc. Numerous general explanations of the mentioned phenomena are often based on merely theoretical assumptions concerning the selected single natural phenomenon. However, the variations between them are so extensive that additional data for every newly discovered example are required; even more, in the Mediterranean domains, where current climate is irregular in time. It is easy to understand that in the geological past, especially during the Neogene and even more in the Quaternary, the oscillations were very frequent and extensive.

The High Karst was firstly the term used for the designation of the Deep Karst belt, while it was treated as an autochthonous megaunit. On this basis, all the general morphologic and hydrologic concepts were established. Then, suddenly, in $1924 \mathrm{~F}$. Kossmat defined this belt as a nappe that is southwest vergent, which means that it tangentially overlies the Adriatic domain. Later on, especially after 1980, when the mobilistic concept of allochthonous tectonics was introduced in the explanation of the distribution of the hydrogeological systems, this has influenced the determination of the divides and catchment areas, often contrary to the superficial geomorphology. The High karst belt is the most complicated "holokarst" ("complete karst") domain, in general. There are to be found plenty of poljes and plains which may not be specific for karst itself, but they may be treated as quite specific morphotectonic and hydrogeologic phenomena in the karst.

The Interior Karst belt is located between the High karst and Pannonian terranes. The general qualifications are that they are dissected displaying reduced karst phenomena, with shallow ground water and rare sinking surficial waters within the same intake area. Often, they are to be found as small karst phenomena overlain by transgressive flysch deposits or under allochthonous magmatic rock bodies.

What are the characteristics of epi-orogenic karst terrains?

The term itself designates that these are deposits originated due to inundation upon an older orogene complex. Therefore, they are called epi-platform formations, which may be disturbed only by post-orogenic tectonic disturbances. This means that they do display true allochthonous structural features. I visited, abroad, some such terrains. However, they did not essentially influence my concept of karst hydrogeology concerning the high complicated orogenic complexes. Therefore, anyone who is more interested in this subject may consult our Karst book, where, also, epi-orogenic karsts are treated, e.g. in the U. S. and Russia.

You have presented many examples which testify that for a reliable interpretation of entangled karst hydrogeologic phenomena, the reconstruction of the tectonic basement is needed. Is it possible, in contrast, that karst types with obvious characteristics can improve geotectonic classification of the areas in question?

Obviously. Let me mention, at least, some of the cases in which some of the tectogenetic and, even more, morphotectonic karst notions have been important for enrichment of geotectonic interpretations, but also for defining new general geotectonic concepts. I may illustrate this by some important examples.

My work at home and abroad was very complex and required acquaintance with the geostructural re- 
lations in broad domains. Therefore, I had to consult not only local but also regional publications, especially geotectonic ones, to correlate them in order to find a common model which could be applicable, not only in further general geologic treatments but also in practice. In many cases it was impossible to select all necessary common notions for finding out a basement for additional investigations and applications. Additional exact data have been provided, by deep boreholes,

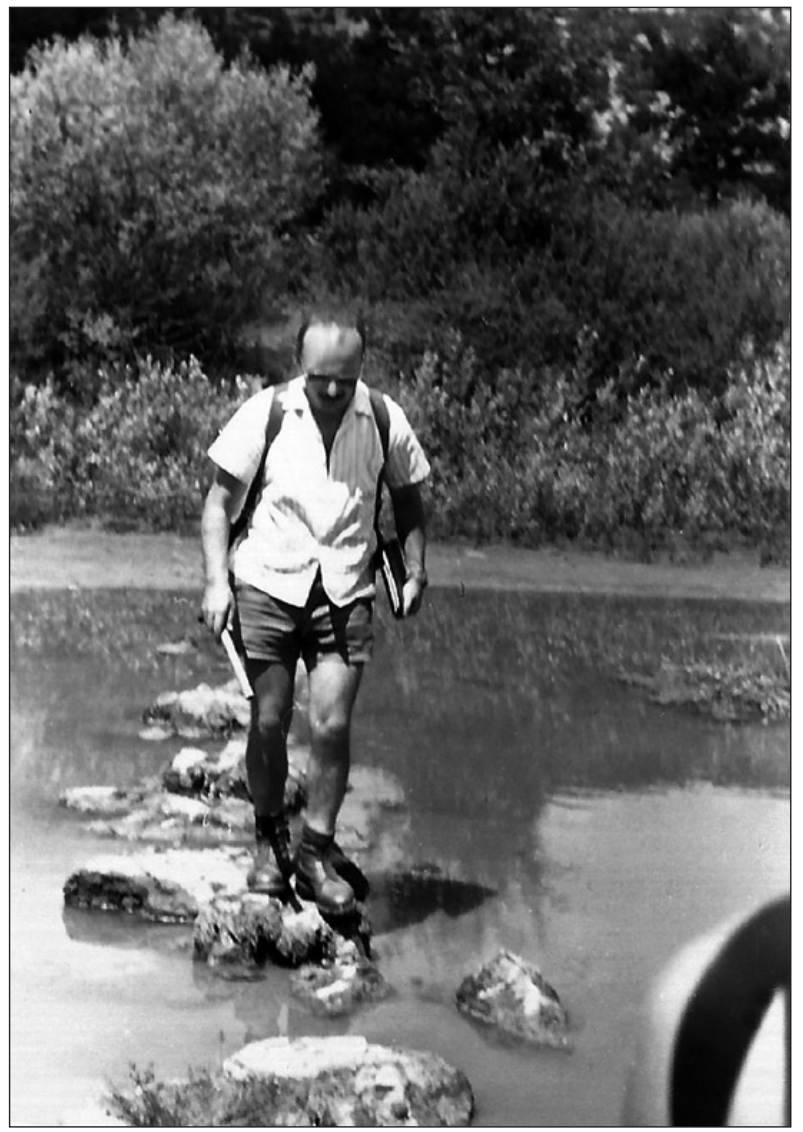

Herak at field work nearby Sveti Rok in Lika, 1960.

dyeing of karst waters, geophysical explorations, and insights into the excavation works at places of construction, which already was going on. Nevertheless, always open questions remained, and most often were included in plans and programs of scientific and teaching institutions.

Will you comment on the institutions in which you were engaged as a karst researcher?

The first was the Museum of natural sciences which, from 1884 to 1940, was also one of the teaching units for geology at the University of Zagreb. My predecessors in the Museum, as karst researchers, were Gjuro Pilar, Dragutin Gorjanović Kramberger and Josip Poljak.
Pilar was our first professional geologist and, from 1884, the first professor of geology. Therefore, he had many obligations and research desires to accomplish. $\mathrm{He}$ did it successfully. However, earlier than he became professor, he had time for some specific problems, including his interest in research of our karst, which has been considered as a prototype of the so-called deep karst. Therefore, many geologists and geographers from abroad, especially from Vienna, visited and were invited to solve some theoretical or practical problems. For this purpose, they cooperated with our non-professional researchers, like the polyhistor Ljudevit (Farkaš) Vukotinović, who was active also in karst research. A very characteristic and important example occurred in 1879 and 1880 . The headquarters of the Croatian-Bosnian Military Zone invited some Viennese geologists to help in solving the lack of water. Pilar insisted on being included in the group, as a home expert, and required personal obligations. He got the area from Karlovac to the Croatian coastline, while the Viennese members of the group were interested in Bosnian karst. The achievements were published bilingually (German and Croatian) in 1874 in Zagreb. Pilar expressed the opinion that the surface waters in the mentioned area have been distributed (in networks or layers), within the major folds as general regulators. The joints and fissures he regarded as local factors. The dynamics of subsurface waters may be characterized by oscillations and periodicity.

\section{And who was the next karst researcher in the Mu-} seum?

Gorjanović was the next, though his main achievements were more connected with the University. He was very active in karst research, though his main scientific works were very diversified. He excavated the former Krapina cave in which were samples of the rests of the famous Pleistocene Krapina man. At the same time he had an interest in karst phenomena in Gorski Kotar, etc. The most interesting was his discussion with the geographer Hinko Hranilović who did not respect, at all, the geological basis of speleogenesis, while Gorjanović had, naturally, the opposite opinion. It is interesting that the problem concerning geotectonics remained, at least partially, open until our time, due to overspecialisation in geosciences.

Poljak, also, was very active.

As a matter of fact, he is the only karst researcher who remained in the Museum throughout his scientific activity. However, his main karst research was connected, also, with other institutions. However, here may be pointed out again that he was the first Croatian speleologist whose descriptive mode of presentation of speleological phenomena converted into the speleogenetic one, taking into account geological mega- and microele- 
ments, which made possible the common definition of hydrologic and morphologic features, in a broader sense and space. His results were published in the Croatian (ex-Yugoslavian) Academy of sciences and arts and were used for his doctoral thesis at the University of Zagreb.

\section{You worked, also, in the Museum.}

I was a member of the Museum from 1943 to 1952. This was the time of my cooperation with Poljak in practical research which was connected, predominantly, with many water power plants, as was mentioned above.

Which organisation was the forerunner of the Croatian geological institute?

In that period there were two working institutions under the leadership of Gorjanović, the Museum and the University. Nevertheless, he was obsessed with establishing a "free state organisation" after the model of "geological surveys" with full competence in geological mapping, in order to cease the submission to such organisations in Austria and Hungary. Despite the political difficulties, he succeeded, and "Geologijsko povjerenstvo" was established with the primary obligation to perform geological mapping. However, Gorjanović proposed to organize some departments, one of which was the Commission of speleology. Poljak, also, was associate member of the Commission, and continued to perform not only geological mapping but also speleological investigations. With the reorganisation of the "Povjerenstvo" into the "Institute" the organized speleological research has been carried out for mapping necessities, or on special orders. Many hydrogeologists have been active in these obligations, while in speleological explorations for practice and popularisations Srećko Božičević was especially active and, as told, his doctoral thesis was prepared by using the scientific speleological notions. More on the development and complex activities may be found in annuals of the Institute, above all in the year 2009, in which its activity during one hundred years is summarised. I want to repeat that, not only I, but also my assistants and students were active, especially in mapping, and so the Institute was a meritorious factor for geological study in connection with field geology, even in projects ordered for practical purposes. Hence, numerous graduate, magister and doctoral theses were prepared, some of which have, already, been mentioned. Among all of them, I want to emphasize the cases from which we all profited due to cooperation of experienced and prospective younger researchers in adopting a common approach to field investigations. In this way many new tectonical notions have been acquired and, obviously, anticipated a new tectonical model.

\section{Will you tell me how it happened?}

My first intention was to prepare a compiled geotectonic map of the Dinarides, on the basis of numer- ous, already published, geological map-sheets, adding my own experience in field investigations, completing them by documents from regional geologic publications, inclusive geologic maps. However, I did not succeed in selection of characteristic correlation elements which, due to essentially different approaches, could be certain proofs for making a basis for a new common model. This stimulated me, in my later investigations, to pay more attention to this problem in my subsequent field research. Then, I recalled the hydrogeologic phenomena at the slope-foot of Mt. Velebit, and especially the allochthonous indications in Gorski Kotar, as well at the lost rivers Fužine and Lokve, as in the broader spring area of the Kupa River.

Soon, new indications of allochthony were multiplied by the help of my students who had to prepare their graduate theses in the area of Skrad and Delnice in Gorski Kotar. During the geological mapping, we established new tangential disturbances (currently we would say subductions or obductions). However, they were not appropriate for a certain explanation within the model of standard geotectonics, on the basis of "geosynclines", as primary orogenetic environments. Although, at that time, "plate-tectonics" was already under discussion, but only for oceanic environments. It was impossible to apply it to our terrestrial investigation areas.

\section{How did you solve this problem?}

We simply continued with our work, in hope that there must be some characteristic tectonic traces, which would help us to come, at least, to some hypothesis, which would be applicable in our interpretations. Fortunately, at that time, for practical purposes, extensive exploration works were executed. The most important were bore holes, dyeing tests on the ponors of sinking rivers and smaller streams, hydrological and geophysical measurements, etc. Most of them were executed to define the conditions for tunnels that were planned along the new railway in the direction of Rijeka.

In this way, our former observations of local allochthonous phenomena have been confirmed, by registration overlying Carboniferous and Triassic deposits upon Jurassic carbonate rocks, at numerous additional places. Therefore, it was logical to conclude that at the level of the proposed tunnels probably no Paleozoic deposits will be encountered, which means that it is not necessary to be afraid of subsurface water accumulations which would cause breakdowns and slides into the excavated tunnel hollows. Moreover, under the allochthonous Paleozoic, in Mesozoic carbonate underground rocks, a very complex net of subsurface streams has been proven. At the same time, the not yet defined superficial catchment areas of the great karst springs such as Zeleni vir, Kupica, Kupa, etc. have been defined by help of dye 
tests, on the basis of which, the subsurface connections between the ponors and springs have been established. In this way not only enlarged subsurface hydrologic nets were proven, but also the nappe-tectonics due to northward underthrusts, even within the crustal domains. The whole tectonic problem between Delnice and Vrbovsko has been understood and published as allochthonous structures (1981), due to north-directed "subductions". Later on, I had the same interpretative approach enlarged in other Dinaric domains. The results were published in processes are quoted in our Karst book (1972). Therefore, I shall limit my commentary only to the main attempts to improve the research organisations that should be entirely devoted to the scientific investigations of our karst domains and specific phenomena.

As told above, Gjuro Pilar, the first professional Croatian geologist, together with Viennese experts, started the exploration of the karst on both sides of the boundary between Croatia and Bosnia, i.e. in the "Croatian Military Zone", in order to find the best way to overcome the lack of water. Pilar tried to explain that the subsurface waters in the Croatian karst are distributed within the major folds as general hydrogeologic regulators of the origin of water layers or networks. He mentions also the joints and fissures, then oscillations and periodicity in water distribution. He believed that the karstification process started, due to endodynamic factors, probably in the Miocene. The Viennese members of the group had different opinions. A. Beyer, a civil engineer, believed only in the isolated flows and possible flow of fresh water under the sea. E. Titze paid great attention to sinking rivers and brooks where fresh water disappears in subsurface irregular cavities, while some brooks flow un-
1986, and, for the first time, the term "continental subduction" was used. Analogously, many nappe-systems may be more precisely explained. Thus, the specific and applied karst investigations "settled the debt" to tectonics and confirmed its significance in karst processes.

Your work in the research of karst areas and phenomena occurred mainly within the institutions in which you worked as their active member or co-worker in special projects. Would you shortly comment on how this was going on?

As I said, my first approaches to karst phenomena were non-professional and influenced by prejudices. Not earlier than when I attended the teaching of Latin and Greek languages, I was acquainted with some karst terms, which was, afterwards, slowly transformed into considerations of some phenomena and their origin. I want to mention that all the most important forms and derground to the sea. He believed that simple hydraulic laws may explain irregular changes in water levels and the appearance of artesian water may be connected with high water levels. It is significant that the members of the same group had such different approaches to the same karst type.

The next steps were made by the geologist Dragutin Gorjanović Kramberger and the geographer Hinko Hranilović. Gorjanović, predominantly, was occupied with human fossil remains (Krapina, Vindija, Medvednica). However, he had scientific interest in the shallow karst between Lower Mrežnica and Lower Dobra rivers, as well as the karst adjoining the ex-plain by Ogulin, etc., while Hranilović had not yet recognized geology as a creative factor in the development of karst phenomena, in general. Therefore, a sharp dispute lasted between them, and the controversies remained until the current 
time, although practice has shown that many karst problems could not be solved without intensive involvement of geology, including petrology.

As a member of Croatian Academy of sciences and arts you are, obviously, well informed how the Academy has supported the explorations of our karst.

It is curious that already in 1938 I was in the group of students that were obliged to conduct field-geological exercises connected with geological mapping in Lika, which was financially supported by the Academy, on request of professor Salopek who was its member. Even as a young professional researcher, I collaborated with the Academy, either as a field researcher, especially in Žumberak and Samobor Mountains, or as the author of other scientific publications, and had the opportunity to take part in some discussions in the Academy. After 1963 as a member of the Academy, I had the opportunity to cooperate in different ways, as author and editor of some Academian publications, guide of some internal associations, member of central authorities of the Academy, etc. In this way I had a good opportunity to follow and help in activities connected with karst research.

Will you give me some additional information concerning the mentioned activity?

The increase of the common interest in karst areas was obvious, especially, in the middle of the twentieth century. In order to intensify exploration and take benefit of karst areas the stimulation of collecting historical data is a basis for new explorations in different scientific fields such as anthropogeography, forestry, agriculture, biotechnics, petrology, geomorphology, geology, hydrology, hydrotechnics, geotechnics, etc. Among the members of the Academy many outstanding researchers in different fields of investigations were, also, interested in karst problems in order to include the notions in the scope of their main scientific branches. Therefore, they initiated the establishment of an integrative unit within which may be possible a common correlation of the data gained by specific research activities. The main protagonists were Aleksandar Ugrenović (forestry), Branimir Gušić (anthropogeography) and Marijan Salopek (geology), and from other members may be pointed out Ivo Pevalek (botanist who explained the role of tufa in the origin of the waterfalls of Plitvice Lakes), Fran Tućan and Luka Marić (geochemistry of limestones), Milivoj Petrik (hydrotechnician), Josip Roglić (geomorphologist), Stjepan Horvatić (phytocoenologist) and (finally) Mirko Malez (speleologist, palaeontologist and palaeoanthropologist). There were, also, many collaborators outside of the Academy. To coordinate the activity, the "Commission for scientific research of karst", was established in 1952, started under the leadership of the geologist Marijan Salopek and finished in 1972. In the meantime, to give more opportunities for correlation of, very often, heterogeneous, achievements, in 1953 the new periodical "Krš Jugoslavije - Carsus Yugoslaviae" was founded and lasted until 1991. In it, authors from the Academy and outside of it (even from abroad) were published. Therefore, Salopek needed some younger assistant with an inclination for organisation of explorations, and who was skilful in arranging a collection of fossils and other scientific documents. His student Mirko Malez had performed such activities at the University, and Salopek engaged him as informal assistant. From the beginning, Malez took initiative, finished the study, and became an outstanding researcher in speleology, palaeontology of mammals and palaeoanthropology, and besides, very active in popularisation of speleologic phenomena, etc. He became, also, an ordinary member of our Academy. On his initiative the "geological collections and laboratory" of the Academy in 1955 officially was pronounced an independent unit, under the name "Geological-Palaeontological collection and Karst laboratory". When Salopek passed away, Malez took charge to lead the whole activity of this institution, which later on changed its name and became "Institute of palaeontology and geology of Quaternary". It is the only institution of the Academy which is still active in research and cooperation with many home and foreign researchers and institutions, such as the faculties of the universities of Zagreb and Zadar, the institutes, museums, and the academies of Slovenia, Austria, Bulgaria, Czech Republic, Georgia, Poland, etc. The researchers of the Institute and their collaborators have published approximately 700 scientific and popular papers, articles and books. The library has increased, the collections are very rich, and the cooperation lasts. Only the support, due to financial difficulties, is diminished, although the Institute is the only specific and independent organisation charged, explicitly, with research of karst phenomena; the "Odbor za krš" (Committee for karst) lasted very briefly.

The speleologic associations, outside of standardized scientific institutions, intensified their activity in speleological explorations and popularisation of karst phenomena, not without some positive scientific results. Though not especially close to this activity, I was invited in 1982 to present my comprehension of the geotectonical frame of speleology at the Yugoslav congress of speleology, in Karlovac. I accepted the invitation very gladly, since this was a sign that speleology and geology are coming closer to one another.

So, for the end of our interview, can you tell us, after 70 years of your fruitful karst career and with regard to the complexity of the subject, which scientific approach could be most appropriate for understand- 


\section{ing karst phenomena holistically or concerning its specific problems?}

Karst research belongs clearly to natural science (geochemistry, hydrology, geomorphology, climatology, geology, palaeoanthropology, zoology, etc.). To acquire commonly acceptable conclusions, cooperation of experts from convergent scientific domains is needed to initiate discussions for acquiring common probable conclusions. The same task may be realized by comparative study of different complementary publications. However, this requires larger education in fundamental natural sciences. Thus, by selection and interdisciplinary joining of supplemented notions it is possible, not only to reconstruct the evolution and existing pattern of different karst types, but also to implement their different morphological and hydrological characteristics within the lithologic and tectonic frames. This requires a very distinctive treatment of synonyms, homonyms, supplemental or autonomous classification terms. I had the opportunity to follow both of the mentioned ways in vast geographic extensions and in diverse, sometimes very complicated karst types, connected with theoretical and practical intentions. In the combination of both research tasks, there have been gained data for scientific improvements establishing the essential influence of allochtho- nous tectonics upon diversification of karst types (e.g. orogenic, epi-orogenic), and vice versa. This has made possible anticipation of some important characteristics of the main morphologic and hydrologic units (fracturing, folding and faulting conditions for mechanical and chemical activity in formation of dolines, pits, ponors, caves and speleothems), definition of surface catchment areas depending on the divides, often in the depressions on mountain slopes instead of along the mountainous ridges), assumption of convergent deep flow of subsurface waters issuing on vaucluse wells and sometimes from capaceous caves, subsurface dispersion of waters lost through capaceous ponors, etc. Important is, also, the establishing of allochthonous structures within the karst megaunits such as karst plains or poljes.

The mentioned and other theoretical notions have been important as a basis for exploration work in designing hydrotechnical or civil engineering projects, because they suggest foresights in preparing the fundamental data for construction of traffic objects (especially tunnels), surface storage of karst waters, exploitation of subsurface waters (in epi-orogenic karst) often under artesian conditions, etc. All this shows that any approach to karst as a whole or to some selected problems is multiple and require adequate treatment. 